\title{
Theories of Universal Human Rights and the Individual's Perspective
}

\section{Linda Walter}

Linda Walter, 29, is research assistant and PhD candidate at European-University Viadrina (Chair of European and International Politics), fellow at the Centre for Internet and Human Rights and is writing her doctoral thesis about the universality of human rights and digital social networks. Linda holds a B.A. in Philosophy and a M.A. in European Studies. Furthermore, Linda is cofounder and board member of wEYE, a secure video platform for buman rights issues. She's been volunteering for Amnesty International and gained experiences at the German Federal Foreign Office, the European Council on Foreign Relations and SAP.

\begin{abstract}
The current scientific debate about the universality of human rights can be structured into a horizontal and a vertical dimension. Whereas the horizontal dimension is about the different ways one can approach the topic "human rights" from different disciplines, the vertical dimension is dealing with the fundamental question whether human rights are universal or particularistic. However, the debate lacks the view of the most important group: the individual human being. Consequently, this paper aims to bring the individual's perspective on universal human rights into focus by a) striking a balance between universal and particularistic views on human rights and b) building on a realistic human nature in order to understand and embrace the individual's conviction. The approach meeting these two criteria is a combination of Rainer Forst's "right to justification" and Richard Rorty's "sentimental education". This is the only way to an individually backed and culturally sensitive universality.
\end{abstract}

Keywords: cultural relativism; human rights; individual; political theory; Rainer Forst; Richard Rorty; right to justification; sentimental education; universality 


\section{Introduction}

"The General Assembly proclaims this Universal Declaration of Human Rights as a common standard of achievement for all peoples and all nations, to the end that every individual and every organ of society, keeping this Declaration constantly in mind, shall strive by teaching and education to promote respect for these rights and freedoms $[\ldots] "$.

This statement is a part of the preamble of the Universal Declaration of Human Rights (UDHR), the most widely accepted declaration of its kind. It clearly proclaims the universality of human rights and it is taking as a given that "every individual" is aware of its universal rights and shall be willing to promote it.

The current scientific debate about the universality of human rights can be structured into what I call a horizontal and a vertical dimension. The horizontal dimension is about the different ways one can approach the topic "human rights" from different disciplines. It is threefold, consisting of the moral question about its normative ideals, the political endorsement of a concrete conception of human rights and its legal implementation (including the actual enforcement on the ground). The vertical dimension adds a second layer to the horizontal dimension by asking for the scope of application of human rights in different cultures. It consequently is concerned with the fundamental question whether human rights are universal or particularistic. All horizontal perspectives of human rights research raise different questions concerning the vertical division between universal and particularistic approaches.

This seems to be a full overview over the possible debates about the universality of human rights. But one main group - if not even the most important group - is often out of focus: the individual as bearer of human rights. Christoph Menke and Arnd Pollmann (2007, p 72) point to this void: "Even though human rights recognize per definition all human beings as equal, not all humans equally recognize human rights." ${ }^{32}$

To make the universal demand that every individual shall promote respect for these rights and freedoms - as stated in the UDHR's preamble - become a reality, an approach has to be found that meets the following two criteria: it has to be universal and culturally sensitive at the same time in order to be universal in scope but to leave no individual with its respective culture aside; and it has to be built on a realistic human nature in order to understand and embrace the individual's conviction. Only if everybody, irrespective of its cultural background, is really convinced of the universal idea of human rights, the latter will actually become universal.

32 Own translation; original text as follows: „Die Menschenrechte anerkennen zwar ihrem Begriff nach alle Menschen gleichermaßen, aber tatsächlich anerkennen nicht alle Menschen gleichermaßen die Menschenrechte." 
In a first step the current debate on universal human rights shall be summarized. The different definitions and debates about human rights according to different disciplines will be summed up in what I call the horizontal dimension. In a second step, the vertical dimension will deal with the question of universality with a focus on the related problem of cultural sensitivity. In a third step, the approaches identified as weakly universal and weakly particularistic of Rainer Forst and Richard Rorty will be described as ideal combination to meet the two criteria mentioned above: Forst bridges the gap between the universal claim and the diverse cultural reality of human rights and, therefore, meets the first criteria. Rorty, on the other hand, deals with the unrealistic description of human nature in most human rights theories (including Forst's theory) and proposes an alternative view.

Consequently, this paper aims to bring the individual's perspective on universal human rights into focus by a) striking a balance between universal and particularistic views on human rights and b) building on a realistic human nature in order to understand and embrace the individual's conviction.

The goal of this paper is to provide an overview over the existing research and to point to an approach that is taking the individual's perspective on universal human rights into focus by combining the theories of Rainer Forst and Richard Rorty. A detailed discussion and an in-depth testing for the presented proposition will be left to further research.

\section{The horizontal dimension: Three perspectives on human rights}

In order to point to the academic void in the research on the universality of human rights it is necessary to set the stage by categorizing the different perspectives on how to approach human rights. Whatever approach you follow, they all ground in an empirical problem, meaning that the reason for their appearance can be traced back to a concrete threat to human beings, to their dignity or freedom, in human history. Haller (2013, p 29) describes it as follows:

"Human rights are negatively oriented towards the real conditions. If human rights theories are proposed and philosophically backed, the reason for its proposal is always an unsatisfactory reality, a painful experience of an affront to human dignity." ${ }^{33}$

33 Own translation; original text as follows: „Menschenrechte orientieren sich negativ an den wirklichen Verhältnissen. Wenn Menschenrechtstheorien aufgestellt und philosophisch begründet werden, so liegt der Grund dafür immer in einer nicht befriedigenden Wirklichkeit, in leidvollen Erfahrungen der Verletzung von Menschenwürde“; cf. also Haspel (2005, p 17). 
Haller clarifies that violations always precede rights. Based on this negative orientation towards reality, a need for further reflection on human rights occurs.

These reflections differ strongly depending on the angle of view taken by the various disciplines dealing with the topic. A first broad but also main division is made inter alia ${ }^{34}$ by Jürgen Habermas (Habermas 1999, p 216) who explicitly states that human rights have a Janus face: one side is related to law and the other to morality. This twofold description also follows an intuitive association of the two words forming the term "human rights". Most scholars build on the same differentiation but add a third perspective, the political one. ${ }^{35}$ These three areas - moral, law and politics - shall therefore be the ones I will refer to.

\section{Moral perspective}

Based on the negative reality as described above an ideal counterpart has been developed: a normative moral perspective on human rights. Tönnies (2001, p 11) clarifies, that this perspectives displays what ought to be and not what is; it cannot be justified scientifically (understanding the term in a narrow and quasi-natural scientific way). Consequently, the moral perspective is an imaginary, normative ideal. Amartya Sen emphasizes that this is the primary character of human rights:

"They [human rights, L.W.] are not principally 'legal', 'proto-legal' or 'ideal-legal' commands. Even though human rights can, and often do, inspire legislation, this is a further fact than a constitutive characteristic of human rights." (Sen 2004, p 319)

Human rights as moral rights are independent of their legal implementation. (cf. Haspel 2005, p

19) They are rights that human beings have just because they are human. To justify this claim most theories rely on the idea of human dignity.

\section{Dignity}

The term dates back to ancient Greece (Haller 2013, p 10) but is firmly in focus of the moral human rights approach only since the enlightenment. Immanuel Kant defined dignity as follows:

34 Cf. Nickel 2013, pp 6; 8-11; Koenig 2005a, pp 10-11; Haller 2013, p 28.

35 Cf. Menke \& Pollmann (2007, pp 25-41); Forst (2013, pp 38-39); Steiner \& Alston (2000), subtitling their work on human rights with „law, politics, morals“; Haspel (2005, pp 19-21), providing the same threefold definition, while adding some hybrid forms like "political theory" moving between the moral and the political dimension; Kühnhardt (1991, p 17), next to politics, ethics and law he also mentions anthropology as perspective which can be seen as a first hint to the missing perspective shown here. 
"What has a price is such that something else can also be put in its place as its equivalent; by contrast, that which is elevated above all price, and admits of no equivalent, has a dignity." (Kant 2002 (originally 1785), Ak 4:434)

There is extensive literature on the meaning of the term "dignity" and its basis as justification for human rights. (cf. Kateb 2011; Rosen 2012; Menke/Pollmann 2008, pp 129-166; Köhler 1999, p 111) What dignity actually means depends on various aspects such as the personal background, the sociological determinants and the point of view. ( cf. Lebech 2009; Düwell 2010, p 68; Toivanen \& Mahler 2006, p 86) There are also voices questioning the benefit of the use of the term in general. (cf. Beitz 2013; Ladwig 2007; Ladwig 2010; Köhler 1999, p 111)

Despite its unclear definition and highly debated benefit, the term "dignity" can be found in nearly every declaration of human rights and often serves as final justification for debates about contested human rights. In fact, it seems to be a construction that is needed to circumnavigate a closely related question: What it is, we human beings have in common that no other creature has?

\section{Human nature}

Human rights are founded on the nature of the human being, meaning that there is something in our nature that justifies the special rights we claim.

"The universal term 'man' already conceals the assertion that all people have an essential quality in common, and it is the same quality, which is considered as dominant over all other heterogeneous qualities that the statement appears to be justified that people are 'equal' despite their apparent diversity." (Tönnies 2001, p 39) ${ }^{36}$

But which quality is it that all human beings have but no other creature? The first decision to make here is whether this answer shall be based on religious beliefs or biological science. Based on the enlightenment and a general conviction of the value of theories, the first path of explanation shall be left aside here ${ }^{37}$ - but there are still a variety of perspectives on the subject. Certainly, the question of human nature is transdisciplinary. Psychologists, sociologists, neuroscientists, philosophers and many more work on mapping human nature. ${ }^{38}$ Concerning human nature as basis for human rights, philosophers dominate the scientific debate about the question which quality every human has in common. From Aristotle to Kant, most philosophers

36 Own translation; original text as follows: „Schon in dem Universale ,Mensch“ liegt die Behauptung, dass alle Menschen eine gemeinsame wesentliche Qualität gemeinsam haben, und es ist dieselbe Qualität, die gegenüber allen anderen, heterogenen Qualitäten als so dominierend angesehen wird, dass die Aussage gerechtfertigt erscheint, die Menschen seien trotz ihrer offensichtlichen Verschiedenheit ,gleich'."

37 For a detailed discussion of this topic see Stevenson, Haberman \& Wright (2013).

38 See inter alia Betzig (1997); Bjorklund \& Pellegrini (2002); Sandis \& Cain (2012); Wells \& McFadden (2006). 
give the same answer: rationality. As Kant said, man is "the only rational creature on earth" (Kant 1963 (originally 1784), p 13). Or to put it in Richard Rorty's words: "Traditionally, the name of the shared human attribute that supposedly 'grounds' morality is 'rationality'." (Rorty 1998, p 171)We have an image of humanity which understands man as capable of reason in a universal sense - and this is the quality that makes us human. As we shall see in chapter three, most influential theories on human rights are based on the idea that rationality is the common quality of humankind.

This insight - and its downsides - will be discussed in more detail bellow.

\section{Political perspective}

Inspired by the normative ideals developed within the moral approach, the political perspective transfers theory into practice. The results emerge from a concrete process based on negotiations between contracting parties.

"Instead of seeing human rights as grounded in some sort of independently existing moral reality, a theorist might see them as the norms of a highly useful political practice that humans have constructed or evolved. Such a view would see the idea of human rights as playing various political roles at the national and international levels and as serving thereby to protect urgent human or national interests." (Nickel 2013, p 7)

Nickel describes human rights here as a political practice. One should be more concerned about an actual list of human rights adopted by political representatives than of its moral foundation.

The idea behind this approach is, as Menke and Pollmann (2007, pp 31-33) sum up, that moral rights are obligations single human beings are liable to. Human rights, however, are obligations political representatives in charge of the public order are liable to.

Two of the most famous theorist of justice and human rights, John Rawls and Charles Beitz, ${ }^{39}$ opt for a political conception of human rights by dealing with the topic only as far as it has developed in contemporary human rights practice. This approach limited to the political dimension implies the basic belief "that a person can accept and use the idea of human rights without accepting any particular view about their foundations. [... It is] about the practical use that human rights do, not their reflection of some underlying moral reality." (Nickel 2013, p 17) From this perspective, human rights are a concrete catalogue which is the outcome of an international exchange.

39 Nickel (2013) and Koenig (2005a) refer to Rawls and Beitz concerning the political concept; Menke \& Pollmann (2007) refer to Rawls. 
"John Rawls distinguishes 'comprehensive religious, philosophical, or moral doctrines,' such as Islam, Kantianism, Confucianism, and Marxism, from 'political conceptions of justice,' which address only the political structure of society, defined (as far as possible) in dependent of any particular comprehensive doctrine." (Donnelly 2007, p 289)

Whereas Rawls (1999, pp 78-81) advocates an abbreviated list of human rights, Beitz (2009) opts for a broader understanding and denies the idea of a minimal interpretation of human rights. (cf. Nickel 2013, pp 16-17) This is only one example of the constant difficulty to decide which norms should be counted as human rights.

The most widely accepted list of human rights is the Universal Declaration of Human Rights (UDHR) adopted in 1948 by the United Nations, ${ }^{40}$ endorsed again by the Vienna Declaration and Programme of Action (VDPA) adopted by 171 states at the World Conference on Human Rights in Vienna in 1993.

\section{Legal perspective}

Whereas the UDHR is only a declaration stating a common will and is not legally binding, it has served as foundation for the following two UN human rights covenants, which are actually legally binding: the International Covenant on Civil and Political Rights and the International Covenant on Economic, Social and Cultural Rights both adopted in 1966. All legally binding conventions - be it the seven UN conventions following the two covenants as well as the optional protocols ${ }^{41}$ or the treaties established by different regional human rights regimes ${ }^{42}$ - are steps toward a legally binding human rights regime. Only by codifying human rights, the political will and the rights written down in the declarations can actually be commanded on the ground:

"Human rights, in a strict sense, are understood as rights that are defined by the fact that they are enshrined (codified) in a legal manner and can in principle also be enforced. Claims become human rights only through their codification according to the principle of legality.“ (Haspel 2005, p 20)43

However, even codified laws hardly make a difference if they're not backed by juridical and executive bodies that can finally enforce rights. Europe and America established regional human rights courts, but most regions, covering the majority of human beings (and human rights

40 For an in depth description of the drafting process and the parties involved see Morsink (1999).

41 Office of the UN High Commissioner for Human Rights (2014).

42 Office of the UN High Commissioner for Human Rights \& International Bar Association (2003).

43 Own translation; original text as follows: "Menschenrechte werden im strengen Sinne als Rechte verstanden, die dadurch definiert sind, dass sie auf legale Weise festgeschrieben (kodifiziert) wurden und prinzipiell auch durchgesetzt werden können. Ansprüche werden erst durch ihre Kodifizierung nach dem Prinzip der Legalität zu Menschenrechten." 
violations), have no bodies to enforce human rights - let alone an international court for human rights to enforce the internationally binding treaties.

"The global human rights regime relies on national implementation of internationally recognized human rights. [...] Enforcement of authoritative international human rights norms, however, is left almost entirely to sovereign states." (Donnelly 2007, p 283)

At least under some UN treaties, quasi-judicial bodies have been founded. Theoretically, "[h] uman rights are norms that help to protect all people everywhere from severe political, legal, and social abuses." (Nickel 2013, p 1) Without the mentioned legal frameworks and the human rights courts, this remains theory.

\section{Vertical dimension: human rights as universal or particularistic}

The three perspectives of the horizontal dimension left aside the role different cultures and their individual understanding of human rights play. The aspect of culture cannot be seen as a fourth perspective - it rather adds another dimension to each of the three horizontal perspectives which is vigorously discussed under the topic "the universality of human rights" - this is what I call the vertical dimension. It is moving between the two opposite poles of universality and particularism.

Concerning the first, Jack Donnelly (2007, p 282) ${ }^{44}$ distinguishes "the conceptual universality implied by the very idea of human rights from substantive universality, the universality of a particular conception or list of human rights." Conceptual universality only states that human rights must be held equally by all - this conception is tied to the moral perspective of human rights as stated in above. It is referred to by statements like this: "By definition, human rights are rights that apply to all human beings and are therefore universal." (Kirchschläger 2011, p 22) The substantive universality, however, is asking for the universal application of a concrete list of human rights and is therefore closely linked to the political and the legal approach described above. By outlining the connection between the two different dimensions of universality it already becomes clear that the horizontal dimension was built on a universal understanding of human rights.

Particularism - often referred to as cultural relativism ${ }^{45}$-, on the other side, first of all questions the statement that human rights are universal; without necessarily supporting diverging human rights concepts. (cf. Kühnhardt 1991, p 135) Most texts of the numerous publications on human rights mention the particularistic view only in passing without going into detail and build, often

44 Ludger Kühnhardt is making a similar division naming conceptual universality just universality and substantive universality applicable universality. (Kühnhardt 1991, pp 138ff).

45 I will use the term "particularistic" human rights following Koenig 2005b - for more details see above. 
implicitly, on a universal understanding of human rights. (cf. Arndt 2000, p 19) To take the universality of human rights implicitly for granted turns a blind eye to reality. Human rights violations often occur because of a lack of mens rea which can be traced back to a particularistic understanding of human rights. Consequently, it is one of the main duties of every approach to human rights to deal with this fundamental question.

To go more into depth, Matthias Koenig (Koenig 2005b) is providing a very well-structured and full picture of the different approaches in the debate on universal or particularistic human rights. He sums up his concept as follows:

Figure 1: Validity and justification of norms in the human rights discourse

\begin{tabular}{|c|c|c|}
\hline & Universal & Particularistic \\
\hline Strong & $\begin{array}{l}\text { Natural law } \\
\text { Rationality }\end{array}$ & $\begin{array}{l}\text { Cultural relativism } \\
\text { Communitarianism }\end{array}$ \\
\hline Weak & Discourse theory & Post modernism \\
\hline
\end{tabular}

Source: Koenig 2005b, p 92.

This table shall be the basis for a further evaluation of the topic by combining it with the definitions given above. In addition, the division made by Koenig will serve as a starting point to identify possible approaches that can meet the two criteria as stated in the introduction: In order to bring the individual's perspective on universal human rights into focus an approach has to a) strike a balance between universal and particularistic views and b) build on a realistic human nature.

\section{Universal human rights}

I already clarified that chapter two was written from a universal point of view. The above mentioned concepts can easily be connected with the table Koenig provides. The two strong universal understandings were already explained: The debate on natural law is based on the nature of human beings and is consequently to assign to what I called the moral approach. Rationality in Koenig's understanding refers to the thoughts of Rawls and Beitz, belonging to the political perspective on human rights.

What is "missing" in the table is the legal conception, for the simple reason that there is no debate about the universality of human rights in law. Either something is positive law and has to 
be enforced or it is not. Questions related to law, like the difference between "natural law" and "positive law" or where law shall be applied, shall be understood as part of the moral or political perspective on human rights.

In addition to the strong universal concepts, Koenig also describes something he calls weak universality. It refers to the discourse theory mainly founded by Jürgen Habermas. He is building the legitimacy for norms on a process of intersubjective understanding achieved by individuals in argument and not like Kant on a thought experiment of the rational individual. For Habermas, individuals need to engage in a discursive justification of human rights to legitimize them. (Habermas 1999; cf. Tönnies 2001, pp 176-191; Koenig 2005b, pp 101-103) Due to its discursive nature the Habermasian approach is suited to build a bridge between the universal and the particularistic approach. One of his scholars submits a theory that seems to be especially promising to strike a balance between the two poles: Rainer Forst, who is said to constitute "the third generation of the Habermasian School" (Suárez Müller 2013, p 1049), developed the "right to justification", arguing that "every norm that is to legitimize the use of force [...] needs to be justifiable by reciprocally and generally non-rejectable reasons." (Forst 2013, p 140) Tying this to the human rights debate, Forst proclaims that the "right to justification" is the one, universal human rights and that it serves as a basis to develop a human rights catalogue in accordance with its procedures. (Forst 2013)

But even though the Habermasian school sets itself apart from Kant by proposing that it is not the single individual but the discursive group that has to justify norms, they have one thing in common: the unrestricted belief in the rational human being. Habermas foresees a perfectly rational process of argumentation by defining presuppositions that are far from real world debates. The same goes for Forst: "Together with Apel and Habermas, Forst defines reason as the search for a universal justification that claims general validity and that must be acceptable for all concerned." (Suárez Müller 2013, p 1051) This also leads to the main criticism: Their approaches state processes that humans owe to one another as rational beings. (cf. Koenig 2005b, pp 102-103)

Consequently, the discursive approach by Forst meets the first criteria but fails to meet the second one - it does not build on a realistic human nature. It is still worth examining it further which will be done bellow.

\section{Particularistic human rights}


The term "particularistic" 46 as opposing to the term "universal" human rights is less common than the term "relative" 47 . However, Koenig's table clarifies that "relativism" or "cultural relativism" is only one out of different possible particularistic strategies of reasoning. Therefore, this paper will follow Koenig's wording.

Cultural relativism, by Koenig classified as strong particularistic approach, basically means what the most widely known statement of relativism by the American Anthropological Association suggests:

"Standards and values are relative to the culture from which they derive so that any attempt to formulate postulates that grow out of the beliefs or moral codes of one culture must to that extent detract from the applicability of any Declaration of Human Rights to mankind as a whole." (The Executive Board, American Anthropological Association 1947, p 542)

Koenig differentiates three different types of relativism: The descriptive relativism states that moral norms vary from culture to culture. Metaethical relativism doubt the existence of a neutral rational method to assess different cultures consequently meaning that norms like human rights can always only be understood from within a certain culture. The third type, called normative relativism, states that the diversity of cultures shall be respected and supported. (cf. Koenig 2005b, pp 9698)

The last category, Koenig opens in his table, is the - classified as weakly particularistic approach of post modernism. Mainly referring to Richard Rorty, Koenig emphasizes the problem nearly all approaches to human rights have in common: their indestructible believe in human beings as rational entities. (Koenig 2005b, pp 100-101)

In his famous essay "Human Rights, Rationality, and Sentimentality" (1998) Rorty is stating that it is not knowledge, respectively rationality, that makes us people become human beings but rather feelings. Rorty clearly doubts the often proclaimed merely rational nature of humans and argues "that since no useful work seems to be done by insisting on a purportedly ahistorical human nature, there probably is no such nature, or at least nothing in that nature that is relevant to our moral choices." (Rorty 1998, p 172)

Hereby, Rorty is providing an alternative to the disproportionally present approach to reduce humans to rational beings. By stating that the foundation of human rights is outmoded (Rorty 1998, p 180), he leaves the question of justification aside. (cf. Barreto 2011, pp 96-99) Koenig

46 Cf. Arndt 2000 who is also using the word „particularistic“.

47 Most authors use the term „relativism“ or „cultural relativism“ cf. Donnelly (2007); Donnelly (2008). 
sees this as a "helpful step on the way to overcome the classical controversy on universalism versus relativism.” (Koenig 2005b, p 100)

This chance, at the same time, has a weak spot: Without reasonable justification there is no possibility to specify the actual content of human rights. The missing clarity on what human rights are leads in turn to the impossibility of Rorty's approach. How can one educate people for a "global moral sentiment" without having a common understanding of human rights?

Nevertheless, to focus on the moral sentiment of humans leads the debate of human rights away from theory, politics and law towards the individual on the ground by drawing a picture of human nature that is much more realistic. Consequently, Rorty supposes a valuable contribution to the second criteria.

\section{The missing debate}

From the current debate about the universality of human rights the following conclusion can be drawn: there are various perspectives on human rights and two main poles in the debate about their universality. Most of the debates are dealing with the subject from a rather abstract point. They are hardly taking into account the most important group concerning the universality of human rights as described in the preamble of the UDHR: the individual human being as a culturally bound creature and its nature. But it is the individual, as the bearer of human rights, who shall be in focus of research.

Even though the main research on the topic is not dealing with the individual, I already pointed to two connecting factors in the preceding chapter: On the universal side, the Habermasian School of discourse theory - and on the particularistic side, the neo-pragmatic approach mainly represented by Rorty. The two approaches do not only take individuals into focus and try to overcome the universal/particularistic controversy; they also seem to complement each other:

One of the main points of critique concerning the Habermasian school of thought including Forst is the continuing concentration on humans as rational beings. Rorty is providing a valuable supplement for this problem. On the other side, Rorty is often criticized because one cannot justify any specific set of human rights - and this is what the right to justification can contribute to.

To connect this again to Koenig's table, one could restructure it as follows: 
Figure 2: Horizontal and vertical dimensions of human rights

\begin{tabular}{|c|c|c|c|c|}
\hline & Moral & political & individual & Legal \\
\hline Universal & Natural law & Rationality & Discourse theory & \\
\hline Particularistic & Cultural relativism & Communitarianism & Post modernism & \\
& & & & \\
\hline
\end{tabular}

\section{Source: own variation of Koenig 2005b, p 92.}

The horizontal dimension as described above can be found in the first row and substitutes Koenig's division into strong and weak theories. The theories formerly defined as "weak" ones are the ones I see the potential in to form a new theory of human rights. The vertical dimension sticks to the division made by Koenig.

An individual approach, as suggested in this paper, has the potential to a) overcome the difference between universal and particularistic angels and b) bring the individual's perspective on the universality of human rights into focus by clarifying the human nature and building on a pragmatic constructivist discourse. To support this claim, I will summarize the relevant theories.

\section{Rainer Forst: The right to justification}

Even though discourse theory is mainly connected to the name of Jürgen Habermas, I will focus on one of his successors, Rainer Forst. By developing the theory of the "right to justification" and applying it to human rights, he is refining discourse theory with the goal to combine universal and particularistic views by claiming to be universal in theory and still particularistically applicable. $^{48}$ (Forst 1999a, p 68) Consequently, he already developed discourse theory into the direction of the first aim of this paper.

First of all, it shall be clarified what the "right to justification" is:

"This basic right to justification is based on the recursive general principle that every norm that is to legitimize the use of force (or, more broadly speaking, a morally relevant interference with other's actions) claims to be reciprocally and generally valid and therefore needs to be justifiable by reciprocally and generally non-rejectable reasons." (Forst 2013, p 140)

48 Forst is not the only author who tries to strike a balance between the two poles (cf. Donnelly 2007), but his account takes the individual's perspective into account. 
All norms meant to be enforced, including human rights, have to be reciprocally and generally justifiable. Reciprocity here means that the author must not assert a claim that is denied to others. By generality Forst means that all affected parties of a norm must be able to equally share the reason for the norm in question. (cf. Forst 1999, p 82; Forst 2013, p 140) The criteria of generality is crucial to reject arguments from the cultural relativist side because it implies that a culture has to redefine its norms as soon as the norm is not equally shared by every member of the culture. Consequently, there is no external pressure on cultural change.

Concerning human rights, this means "that human rights are meant to ensure that no human being is treated in a way that could not be justified to him or her as a person equal to others" (Forst 2013, p 39). According to Forst, one has to take as a given that there is only one basic human right: the right to justification. Thereby, this does not mean that the other human rights can be developed from this right - it rather serves as a main guide for the construction of concrete human rights.

"The basic right does not determine from the outset which substantial reasons are adequate, which rights can be demanded, or which institutions or social relationships can be justified. As the universal core of every internal morality, the right to justification leaves this to the members' specific cultural or social context." (Forst 1999b, p 42)

The underlying notion here is that every human being is recognized as a person to whom another person owes a justification of the reasons for their actions. (cf. Forst 1999b, p 44) The only criteria these justifications have to fulfill are - as already mentioned above - reciprocity and generality. These rights shall then be made socially effective in two aspects: Human rights must be a) substantive, meaning here that the formulated rights must express adequate forms of mutual respect, and b) procedural, meaning that everyone who is living under certain rules has to have the possibility to participate in the determination of these rules. (Forst 2013, p 39)

This moral constructivism can lead to an abstract list of human rights - this is why moral constructivism always has to be accompanied by political constructivism, meaning that these rights must also be justifiable in a concrete political order. (cf. Forst 1999b, p 48)

"The right to justification in this legal-political context does not fall prey to Frank Michelman's reducito ad absurdum according to which any interpretation of human rights would only be legitimate in a state if it could be accepted concurrently in a more or less 'pure' procedure. Rather, it means that in procedures of political justification that exclude no one arbitrarily, no fundamental, reciprocally and generally irrefutable claims are ignored;" (Forst 1999b, pp 59, note 29)

Concerning the internationalization of this concept, Forst denies the necessity of a "world state". He rather proclaims that humans - as moral persons and citizens of a state - are "world citizens" 
who consequently are obliged to not only respect the human rights of others but also to actively support them when they become victims of human rights violations. (cf. Forst 1999b, p 53)

As already mentioned above, one of the main problems of Forst's approach is that he takes the rational nature of human beings for granted:

"Reason, according to Forst, is inescapable and therefore it is nonsensical to ask 'Why be rational?'. Asking or answering this question already implies a commitment to rationality. And this, according to Forst, also applies to the question 'Why be moral?’" (Suárez Müller 2013, p 1053)

\section{Richard Rorty: Sentimental education}

According to Richard Rorty, this last question "Why be moral?” is already the wrong approach:

"[...] one will see it as the moral educator's task not to answer the rational egoist's question 'Why should I be moral'?' but rather to answer the much more frequently posed question 'Why should I care about a stranger, a person who is no kin to me, a person whose habits I find disgusting?' The traditional answer to the latter question is 'Because kinship and custom are morally irrelevant, irrelevant to the obligations imposed by the recognition of membership in the same species.' This has never been very convincing, since it begs the question at issue: whether mere species membership is, in fact, a sufficient surrogate for closer kinship. [...] A better sort of answer is the sort of long, sad, sentimental story that begins, 'Because this is what it is like to be in her situation - to be far from home, among strangers,' or 'Because she might become your daughter-in-law,' or 'Because her mother would grieve for her."' (Rorty 1998, pp 184-185)

What Rorty is criticizing here is the idea that sentiment is weaker than reason, that human beings are understood as purely rational. In his work on human rights he is referring to Annette Baier's understanding of David Hume's moral theory. According to Hume "[r]eason is, and ought only to be the slave of the passion, and can never pretend to any other office than to serve and obey them." (Hume s.a., 127) Baier sums up that Hume - in difference to Kant - "claims that morality rests ultimately on sentiment" (1994, pp 56). This is why Rorty suggests answering to the above stated question rather with a sentimental story than with a rational argument. His suggestion is to make security and sympathy the main values for a human rights culture:

"By 'security' I mean conditions of life sufficiently risk-free as to make one's difference from others inessential to one's self-respect, one's sense of worth. [...] By 'sympathy' I mean the sort of reactions [...] that whites in the United States had more of after reading Uncle Tom's cabin than before, the sort we have more of after watching television programs about the genocide in Bosnia." (Rorty 1998, p 180)

What Rorty hopes for is to enliven "the global moral sentiment and of constructing a worldwide ethos favourable to human rights." (Barreto 2011, p 112) Barreto sums up perfectly what Rorty has in mind:

"Rorty defends the epistemological presupposition of the contingency of human rights, understands rights and morality in terms of human suffering, and elaborates the idea of advancing human sensibility to 
consolidate the rights culture. He thematizes the concept of a 'global moral sentiment' and finds in sympathy and solidarity the appropriate feelings and values for a human rights culture." (Barreto 2011, p 93)

Reference should be made to the fact that Rorty's approach is the only one that is addressing the main root of the problem that leads to the lack of research into the individual's perspective of the universality of human rights: He questions the mere rational nature of humans and develops an advanced understanding of the human race.

On the other hand, Rorty's approach has two main deficits: It lacks the ability to opt for a specific (not necessarily immutable) catalogue of human rights. Furthermore, Rorty's global moral sentiment underlies the implicit presupposition that we all feel the same, when we hear a sad story about a human rights violation. (cf. Menke \& Pollmann 2007, pp 60-68) But maybe, some people have to be "reeducated" concerning their feelings, especially those who "decided" to exclude certain human groups from being human. To be able to do this, one needs a common understanding of human rights - and this is where Forst comes in again.

\section{Justifying sentimental education}

The aim of this paper is to bring the individual's perspective on universal human rights into focus by a) striking a balance between universal and particularistic views on human rights and b) building on a realistic human nature in order to understand and embrace the individual's conviction. Each of the two approaches described in this chapter fulfills one of the criteria. Adding up the critical counter-arguments from the two approaches described, it seems obvious to combine them and consequently develop an approach that leads to an individually backed and culturally sensitive universality.

Forst is striking a balance between the universal and the particularistic approach but his approach is based on a rational human nature. Rorty, on the other hand, does not combine universal and particularistic views but he develops an alternative understanding of human nature and points out that it is more important to educate people sentimentally than to rationally justify a norm.

One can combine the two approaches to a new one that meets both criteria and therefore brings the individual's perspective of human rights into focus. Security, the precondition brought forward by Rorty, is the framework the whole approach is located in. Within this framework the two authors can be combined as follows: Whereas Forst provides a reasonable structure on how to develop a buman rights catalogue based on its two criteria of reciprocity and generality, Rorty deals 
with the question how to convince people to act in accordance with the developed catalogue by using sentimental education. In a first step, a culturally sensitive catalogue can be developed on the basis of the universal right to justification, in a second step, this (temporarily) fixed catalogue is used as a guideline for defining the normatively best goals for sentimental education. The universal, global human rights catalogue consists of reciprocal and general norms accepted by all human beings. In addition to this global catalogue, every culture can develop its own, more detailed catalogue in accordance with the criteria brought forward by the right to justification. Local norms that do not meet the two criteria - for example because a certain group within a cultural entity brings forward reasonable arguments against a certain norm - have to be revised.

Figure 3: Justifying sentimental education

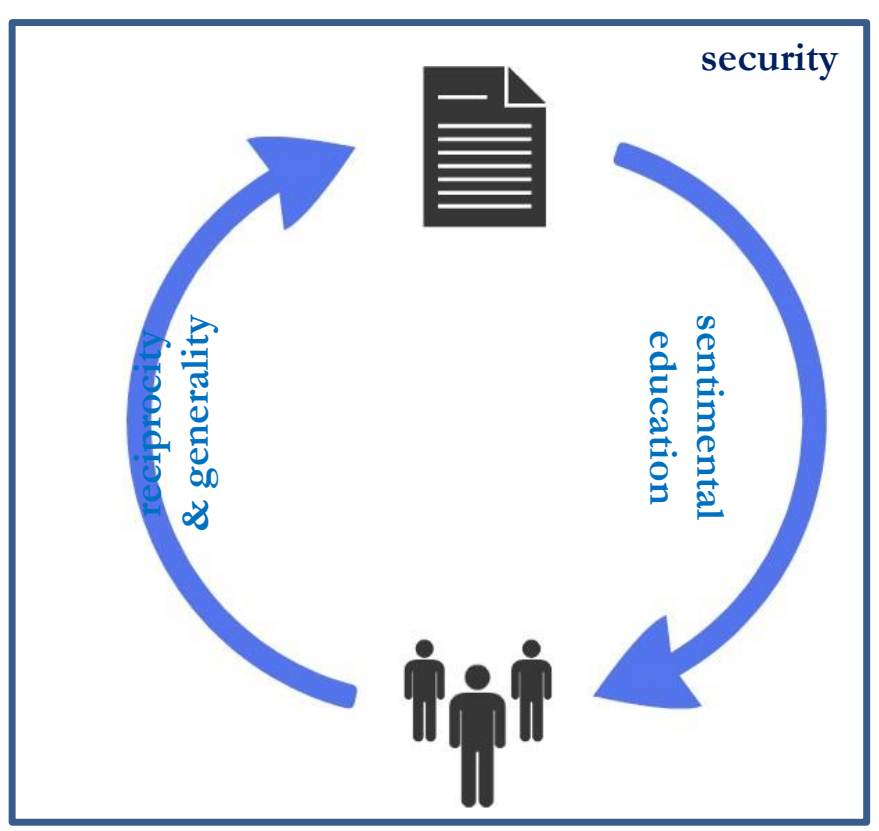

\section{Source: author.}

This is an ongoing process: As soon as somebody brings forward reciprocally and generally nonrejectable reasons to change a certain human right the human rights catalogue has to be modified. If somebody cannot justify his claim by reciprocal and general reasons the declaration remains unchanged and the process of sentimental education takes over.

If the individual knows that it could bring forward arguments to change the human rights set but on the other hand is "sentimentally educated" to feel for its fellow human beings it either starts to be convinced of the human rights already stated or it can bring forward general and reciprocal reasons why it is not. Like this, the individual's perspective on human rights becomes the center of the theory. 
The presented idea merely serves as a first outline for an approach that is focused on the individual's perspective. An in-depth testing and further research on the presented proposition must follow.

\section{Outlook}

Whereas the landscape of human rights theories dealing with its universality is broadening more and more, perspectives focusing on the individual are still underrepresented. The approach to combine the theories of Richard Rorty and Rainer Forst is a first idea on how to proceed here. It gives every individual the chance to change a set of human rights by bringing forward justifiable reasons - but it also puts straight that a process of justification cannot convince people of any proclaimed norm. This is only possible by sentimental education. By allowing for a realistic nature of humans and a culturally sensitive universalism the approach brings the individual perspective of human rights into focus.

To follow this direction is especially compelling because the validity of the idea of sentimental education might be verifiable via the social web. Taking the actual set of human rights as stated in the UDHR and the following treaties as a given ${ }^{49}$ (because they are justifiable by reciprocal and general reasons) the second part of the presented idea comes into play: How can one effectively realize sentimental education around the globe? The structural possibilities of the social web are strengthening and prolonging connections to acquaintances and - as Granovetter (1973) already stated 40 years ago - these weak ties often have a stronger impact on us than our close friends. (cf. Golbeck 2013) Consequently, digital social networks might be the port of call for taking the individual's perspective into account by using the social web to put sentimental education into practice.

In 1948 Eleanor Roosevelt's answered to the question “Where Do Universal Rights Begin?” as follows:

"In small places, close to home-so close and so small that they cannot be seen on any maps of the world. Yet they are the world of the individual person; the neighborhood he lives in; the school or college he attends; the factory, farm or office where he works. Such are the places where every man, woman, and child seeks equal justice, equal opportunity, equal dignity without discrimination. Unless these rights have meaning there, they have little meaning anywhere. Without concerted citizen action to uphold them close to home, we shall look in vain for progress in the larger world." (Youth for Human Rights International 2014)

49 Donnelly (2008) points out why this assumption, which is counterintuitive at first sight, is actually reasonable. 
In 2014, her statement still seems to be understandable, but the second part is outdated. Nowadays, we can possibly reach out to the whole world with one sentimental video via the social web. This may be our chance to speed up the "progress in the larger world" - and it would be one more step to an individually backed and culturally sensitive universality. 


\section{Bibliography}

Arndt, C (2000): Die Menschenrechte. partikularistische Ansätze zur Begründung ibrer Universalität, Hamburg.

Baier, A (1994): 'Hume, the Women's Moral Theorist?' in Moral prejudices. Essays on ethics, ed A Baier, Harvard University Press, Cambridge, Mass., pp. 51-75.

Barreto, J (2011): 'Rorty and human rights. Contingency, emotions and how to defend human rights telling stories', Utrecht Law Review, vol. 7, no. 1, pp. 93-112 [30 July 2014].

Beitz, CR (2013): 'Human Dignity in the Theory of Human Rights: Nothing But a Phrase?', Philosophy \& Public Affairs, vol. 41, no. 3, pp. 259-290 [18 December 2013].

Betzig, LL (1997): Human nature. A critical reader, Oxford University Press, New York.

Bjorklund, DF \& Pellegrini, AD (2002): The origins of human nature. Evolutionary developmental psychology, American Psychological Association, Washington, DC.

Donnelly, J (2007): 'The relative universality of human rights', Human Rights Quarterly, vol. 29, no. 2, pp. 281-306.

Donnelly, J (2008): 'Relativity and the Universal Declaration', eJournal USA, vol. 13, no. 11, pp. 33-37.

Düwell, M (2010): 'Menschenwürde als Grundlage der Menschenrechte', Zeitschrift für Menschenrechte, vol. 1, pp. 64-79.

Forst, R (1999a): 'Das grundlegende Recht auf Rechtfertigung. Zu einer konstruktivistischen Konzeption von Menschenrechten' in Recht auf Menschenrechte. Menschenrechte, Demokratie und internationale Politik, eds H Brunkhorst, WR Köhler \& M Lutz-Bachmann, Suhrkamp, Frankfurt am Main, pp. 66-105.

Forst, R (1999b): 'The Basic Right to Justification: Toward a Constructivist Conception of Human Rights', Constellations, vol. 6, no. 1 [01 September 2014].

Forst, R (2013): Justification and critique. Towsards a critical theory of politics, Polity, Cambridge.

Golbeck, J (2013): Analyzing the social web, Elsevier, Amsterdam.

Granovetter, MS (1973): 'The Strengh of Weak Ties', American Journal of Sociology, vol. 78, no. 6, pp. 1360-1380.

Habermas, J (1999): 'Der interkulturelle Diskurs über Menschenrechte' in Recht auf Menschenrechte. Menschenrechte, Demokratie und internationale Politik, eds H Brunkhorst, WR Köhler \& M LutzBachmann, Suhrkamp, Frankfurt am Main, pp. 216-227.

Haller, G (2013): Menschenrechte obne Demokratie? Der Weg der Versöbnung von Freibeit und Gleichbeit, Bpb Bundeszentrale für Politische Bildung, Bonn. 
Haspel, M (2005): 'Menschenrechte in Geschichte und Gegenwart' in Menschenrechte, ed S Frech, Wochenschau Verl., Schwalbach/Ts, pp. 15-40.

Hume, $\mathrm{D}$ s.a., A treatise of human nature. in two volumes. 2, Dent, London.

Kant, I (1963[1784]): 'Idea for a Universal History from a Cosmopolitan Point of View. Translated by Lewis White Beck' in On history. Translated by Lewis White Beck, Robert E. Anchor and Emil L. Fackenheim, ed I Kant, Indianapolis.

Kant, I (2002[1785]): Groundwork for the metaphysics of morals, Yale University Press, New Haven.

Kateb, G (2011): Human dignity, Belknap Press of Harvard University Press, Cambridge, Mass.

Kirchschläger, P (2011): 'Universality of Human Rights' in The EWC Statement Series, pp. 22-25.

Koenig, M (2005a): Menschenrechte, Campus Verlag, Frankfurt am Main.

Koenig, M (2005b): 'Universalismus und Relativismus - Zur Begründbarkeit der Menschenrechte' in Menschenrechte, ed S Frech, Wochenschau Verl., Schwalbach/Ts, pp. 91-112.

Köhler, WR (1999): 'Das Recht auf Menschenrechte' in Recht auf Menschenrechte. Menschenrechte, Demokratie und internationale Politik, eds H Brunkhorst, WR Köhler \& M Lutz-Bachmann, Suhrkamp, Frankfurt am Main, pp. 106-124.

Kühnhardt, L (1991): Die Universalität der Menschenrechte, Bundeszentrale für Politische Bildung, Bonn.

Ladwig, B (2007): 'Menschenrechte und menschliche Natur. Bausteine zu einer kritischen Theorie der Menschenrechte', Leviathan 1.

Lebech, M (2009): On the problem of human dignity. A hermeneutical and phenomenological investigation, Königshausen \& Neumann, Würzburg.

Menke, C \& Pollmann, A (2007): Philosophie der Menschenrechte qur Einführung, Junius, Hamburg.

Morsink, J (1999): The Universal Declaration of Human Rights. Origins, drafting, and intent, University of Pennsylvania Press, Philadelphia.

Nickel, J (2013): Human Rights. Available from: http://plato.stanford.edu/archives/ win2013/entries/rights-human/ [24 February 2014].

Office of the UN High Commissioner for Human Rights 2014, Core International Instruments. Available from: http://www.ohchr.org/EN/ProfessionalInterest/Pages/CoreInstruments.aspx [04 September 2014].

Office of the UN High Commissioner for Human Rights \& International Bar Association 2003, Human Rights in the Administration of Justice: A Manual on Human Rights for Judges, Prosecutors and Lanyers. Available from: http://www.ohchr.org/Documents/Publications/ training9Titleen.pdf [31 July 2014]. 
Rawls, J (1999): The law of peoples ;: With, The idea of public reason revisited, Harvard University Press, Cambridge, Mass.

Rorty, R (1998): 'Human Rights, Rationality, and Sentimentality' in Truth and progress, ed R Rorty, Cambridge University Press, Cambridge, New York, pp. 167-185.

Rosen, M (2012): Dignity. Its history and meaning, Harvard University Press, Cambridge, Mass.

Sandis, C \& Cain, MJ (2012): Human nature, Cambridge University Press, Cambridge, UK, New York.

Sen, A 2004, 'Elements of a theory of human rights', Philosophy \& Public Affairs, 32(4): 315-356.

Steiner, HJ \& Alston, P (2000): International human rights in context. Law, politics, morals : text and materials, Oxford University Press, Oxford, New York.

Stevenson, LF, Haberman, DL \& Wright, PM (2013): Twelve theories of human nature, Oxford University Press, New York.

Suárez Müller, F (2013): 'Justifying the right to justification: An analysis of Rainer Forst's constructivist theory of justice', Philosophy \& Social Criticism, vol. 39, no. 10, pp. 1049-1068 [31 August 2014].

The Executive Board, American Anthropological Association (1947): 'Statement on Human Rights', American Anthropologist, New Series, Vol. 49, No. 4, Part 1, vol. 49, 4:1, pp. 539-543.

Toivanen, R \& Mahler, C (2006): Menschenrechte im Vergleich der Kulturen.

Tönnies, S (2001): Der westliche Universalismus. Die Denkwelt der Menschenrechte, Westdt. Verl., Wiesbaden.

Wells, RH \& McFadden, J (2006): Human nature. Fact and fiction, Continuum International Pub. Group, London, New York.

Youth for Human Rights International 2014, Universal Declaration of Human Rights. Available from: http://www.youthforhumanrights.org/what-are-human-rights/universal-declaration-of-humanrights/introduction.html [28 July 2014]. 